\title{
The unpredictable carbon nanotube biocorona and a functionalization method to prevent protein biofouling
}

Lorena García-Hevia ${ }^{1 *+}$ (], Mahsa Saramiforoshani ${ }^{1 \dagger}$, Jorge Monge ${ }^{2}$, Nerea Iturrioz-Rodríguez ${ }^{1,4}$, Esperanza Padín-González 1,5, Fernando González ,3, Lorena González-Legarreta1,3, Jesús González and Mónica L. Fanarraga ${ }^{1}$

\begin{abstract}
Background: The intrinsic physicochemical properties of carbon nanotubes (CNTs) make them unique tools in nanotechnology. Their elemental composition, resilience, thermal properties, and surface reactivity make CNTs also of undisputed interest in biotechnology. In particular, their extraordinary ability to capture biomolecules on their surface makes them essential in this field. The proteins adsorbed on the CNTs create a biological coating that endows them the ability to interact with some cell receptors, penetrate membranes or interfere with cell biomechanics, thus behaving as an active bio-camouflage. But some of these proteins unfold, triggering an immune response that unpredictably changes the biological activity of CNTs. For this reason, the control of the biocorona is fundamental in the nanobiotechnology of CNTs.

Results: Using TEM and AFM here we demonstrate a significant increase in CNTs diameter after protein functionalization. A quantitative analysis using TGA revealed that between 20 and $60 \%$ of the mass of functionalized nanotubes corresponds to protein, with single-walled CNTs capturing the highest amounts. To qualitatively/quantitatively characterize these biocoatings, we studied the biochemical "landscape" of the proteins captured by the different nanotubes after functionalization under various conditions. This study revealed a significant variability of the proteins in the corona as a function of the type of nanotube, the functionalization temperature, or the time after exposure to serum. Remarkably, the functionalization of a single type of CNT with sera from various human donors also resulted in different protein landscapes. Given the unpredictable assortment of proteins captured by the corona and the biological implications of this biocoating, we finally designed a method to genetically engineer and produce proteins to functionalize nanotubes in a controlled and customizable way.
\end{abstract}

Conclusions: We demonstrate the high unpredictability of the spontaneous protein corona on CNTs and propose a versatile functionalization technique that prevents the binding of nonspecific proteins to the nanotube to improve the use of CNTs in biomedical applications.

Keywords: Carbon, MWCNT, SWCNT, Serum, SDS-PAGE, Biotechnology

*Correspondence: Igarcia@idival.org

†Lorena García-Hevia and Mahsa Saramiforoshani contributed equally to

this work

${ }^{1}$ The Nanomedicine Group, University of Cantabria-IDIVAL,

39011 Santander, Spain

Full list of author information is available at the end of the article

c) The Author(s) 2021. This article is licensed under a Creative Commons Attribution 4.0 International License, which permits use, sharing, adaptation, distribution and reproduction in any medium or format, as long as you give appropriate credit to the original author(s) and the source, provide a link to the Creative Commons licence, and indicate if changes were made. The images or other third party material in this article are included in the article's Creative Commons licence, unless indicated otherwise in a credit line to the material. If material is not included in the article's Creative Commons licence and your intended use is not permitted by statutory regulation or exceeds the permitted use, you will need to obtain permission directly from the copyright holder. To view a copy of this licence, visit http://creativeco mmons.org/licenses/by/4.0/. The Creative Commons Public Domain Dedication waiver (http://creativecommons.org/publicdomain/ zero/1.0/) applies to the data made available in this article, unless otherwise stated in a credit line to the data. 


\section{Background}

Carbon nanotubes (CNTs) represent a highly versatile heterogeneous family of uni-dimensional nanomaterials that display many extraordinary properties in different industrial fields [1, 2]. These carbon-nanofilaments, discovered by Iijima in 1991 [3] have held a fundamental role in nanotechnology due to their outstanding physical-chemical behavior that makes CNTs indispensable for many industrial applications, being some of the most promising candidates for the design of multifunctional nanomaterials. More recently, CNTs have been incorporated into the biotechnological field driving major advances and a large potential impact on medical developments. Among the CNTs properties, stands out one with important implications in biotechnology, their high surface reactivity. These nanomaterials have a huge surface-to-weight ratio, calculated in ca. $1000 \mathrm{~m}^{2} / \mathrm{g}$ for single-walled CNTs (SWCNTs) and ca. $350 \mathrm{~m}^{2} / \mathrm{g}$ for multi-walled (MWCNTs) (5 walls) [4], a fact that, together with the intrinsic reactivity of graphene, makes the surface of the CNTs have an enormous capacity to interact with their environment and capture all kind of molecules from any source. This superficial property of CNTs that represents a breakthrough in the fields of drug delivery or nanotherapy, can also be a major handicap if not properly controlled. In this sense, CNTs can behave as Trojan's vectors introducing undesired chemicals or toxins in living organisms [5-7]. But this property makes CNTs excellent delivery vectors for transporting many different molecules, that do not need to be chemically modified for their loading. Among others, CNTs have been used to transport doxorubicin [8-10], or 5-fluorouracil [11-14], but also large quantity/variety of biomolecules including nucleic acids [15-17], or proteins [15].

When CNTs are exposed to biological environments, they get coated with the surrounding biomolecules, mainly proteins, which are active components that significantly modify the properties of nanotubes in biological contexts. Detailed proteomic identification studies have documented the promiscuous nature of CNTs where more than 750 different human proteins have been identified on the nanotube corona upon exposure to human serum or human cell extracts. Among these, immunoglobulins, albumin, fibrinogen, and complement are the most abundant [17-21]. The implications of the coating are pivotal as it provides CNTs with a bio-identity, transforming these nanomaterials into bioactive nanostructures that can participate or interfere in specific cellular functions, often triggering unpredictable interactions. For example, albumin on nanotubes triggers receptormediated endocytosis by most cells [22-25], while antibody or complement adsorption on their surfaces can trigger recognition by phagocytes, and elimination [26].
But CNTs, often taken as a unique nanomaterial, are morphologically and chemically diverse, and this is important in their interaction with the surrounding biomolecules. Previous studies show how the initial binding forces implicated in protein adsorption onto CNTs are hydrogen bonds [27]. Depending on the nanotube diameter and curvature [28], protein structural changes -such as partial unfolding- are also important in the final protein coating $[19,29]$. This way, small nanotube diameters of ca. 1-2 $\mathrm{nm}-$ in the range size of globular proteinshave been reported to prompt more structural changes in proteins than tubes of smaller or larger diameters [19, 29]. Furthermore, recent studies show how the degree of folding of these corona proteins can significantly trigger inflammation, including the production of proinflammatory cytokines and innate immune responses [29]. All these facts suggest that spontaneous CNT coronas and their effects are highly unpredictable, and this could elicit completely different cellular and/or organic responses. In line with this, the diameter of the nanotube has been shown to trigger different biological effects [3, 19, 3034]. SWCNTs, for example, preferentially cause DNA damage [35, 36], while MWCNTs mainly interfere with the cytoskeletal proteins, hindering cellular biomechanics $[37,38]$.

Hence, given the in vivo implications of CNTs corona, here we want to understand the factors that influence the protein coating of nanotubes. In this study, we take into account factors such as the properties of the surface of the nanotubes, the size of the nanotube, the temperature during functionalization, or the particularities of biological media, all critical aspects in nanobiotechnology. Finally, we develop a method to customize and control the CNTs corona with recombinant proteins designed and produced ad-hoc. This method also prevents nonspecific protein biofouling and denaturation of the synthetic coating protein.

\section{Results}

Numerous studies show that CNTs capture a high number of proteins on their surfaces but few papers demonstrate the morphological and mass implications of functionalization. As a first objective, we wanted to identify morphological changes on CNTs upon protein coating using transmission electron microscopy (TEM) and atomic force microscopy (AFM). Figure 1 shows TEM and AFM images of pristine MWCNTs before and after functionalization with serum proteins. Both TEM and AFM techniques reveal a significant enlargement of the diameter of the tubes.

To calculate the amount of protein adsorbed on this bio-coating, we functionalized different nanotubes, namely pristine SWCNTs (SWCNTs), pristine MWCNTs 
(MWCNTs), and oxidized MWCNTs (o-MWCNTs) with bovine serum as a standard protein mixture (Materials and Methods), and performed a thermogravimetric analysis (TGA) in the presence of oxygen. Results shown in Fig. 2 demonstrate how, upon temperature rise, pristine (non-functionalized) SWCNTs displayed a single mass loss observed at approximately $600{ }^{\circ} \mathrm{C}$, corresponding to the combustion of carbon. In serum functionalized SWCNTs the loss of mass below $600{ }^{\circ} \mathrm{C}$ corresponded to the combustion of organic matter. This mass reduction was observed in two steps, $200-400{ }^{\circ} \mathrm{C}$, and $400-600{ }^{\circ} \mathrm{C}$. Thus, the calculated loss of mass corresponding to biomolecules (mostly proteins) in functionalized SWCNTs corresponded to approximately $60 \%$ of the mass of the functionalized nanotubes.

Pristine MWCNTs displayed a single mass loss observed at ca. $550{ }^{\circ} \mathrm{C}$, corresponding to the combustion of carbon. The same nanotubes functionalized with serum displayed a two-step mass reduction (two different slopes), at $250-400{ }^{\circ} \mathrm{C}$ and $400-550^{\circ} \mathrm{C}$ as a result of the combustion of the organic matter. Here, the calculated mass of the biocorona approximately corresponded to $30 \%$ of the functionalized MWCNTs weight.

Finally, the mass loss observed in non-functionalized o-MWCNTs occurred in two slopes. The first $\left(100-550{ }^{\circ} \mathrm{C}\right)$, corresponding to the oxidized groups (approximately 45\%), and the second (from $550{ }^{\circ} \mathrm{C}$ ), corresponding to the combustion of carbon, starting at approximately the same temperature as in observed for pristine MWCNTs. This second mass loss corresponded to ca. $40 \%$ of the mass. Upon functionalization with proteins, o-MWCNTs displayed an extra mass drop between temperatures $250-550^{\circ} \mathrm{C}$ that represented the total sum of the organic matter (serum proteins) added to the oxidized group combustion. Taking into account that the loss of mass that corresponded to the oxidized groups was $45 \%$, the final calculated protein mass in functionalized o-MWCNTs was ca. $20 \%$ of the total weight of the biofunctionalized o-MWCNTs. Summarizing, the percentage of mass that corresponded to the protein adsorbed on the surface of the CNTs depended on the size and properties of the nanotubes, and fluctuated between 20 and $60 \%$ of the total mass of the functionalized CNTs, with SWCNTs capturing the highest amounts. These percentages confirmed that CNTs adsorbed enormous amounts of proteins, especially SWCNT (as represented in Fig. 2 diagram) and that in vivo, this bio-camouflage will be pivotal in driving CNTs interactions with the different biological systems.

Our next step was to understand whether the quantitative and qualitative composition of the corona was predictable or constant. To do this, we explored changes as a function of the CNT type, for it is known that the variety of proteins on the nanotube surface is strongly influenced by the diameter, the hydrophobicity, or functional groups on the surface of the CNTs [28]. For instance, oxidized nanotubes bind more variety of proteins than pristine nanotubes, and proteins that bind SWCNTs have a low affinity for MWCNTs [39]. But we would like to compare the proteins that bind to different nanotubes exposed to the same biological media -in this case, bovine serumusing an identical functionalization protocol.

To visually and straightforwardly evaluate these biocoatings -quantitatively and qualitatively -, we compare the different biochemical protein "landscapes" on functionalized CNTs. To do this, the total protein on the surface of the different functionalized CNTs was stripped with Laemmli buffer. The obtained protein solution was then loaded on SDS-PAGE gels for biochemical analysis and, upon electrophoresis, gel staining (Additional file 1: Fig. S3), scanning, and digital analysis, the protein "landscapes" were calculated. Hence these green profiles display a visual qualitative and quantitative representation of the protein distribution for each type of CNTs (Materials and Methods).

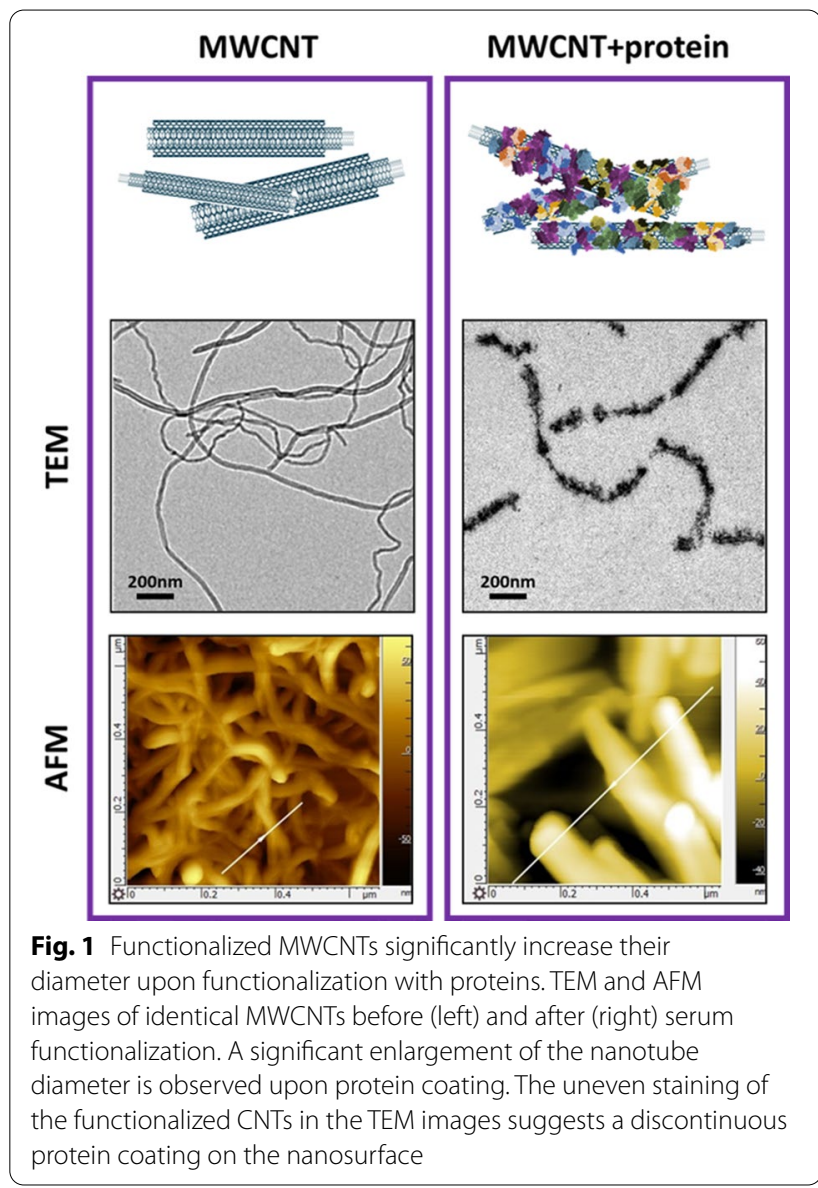




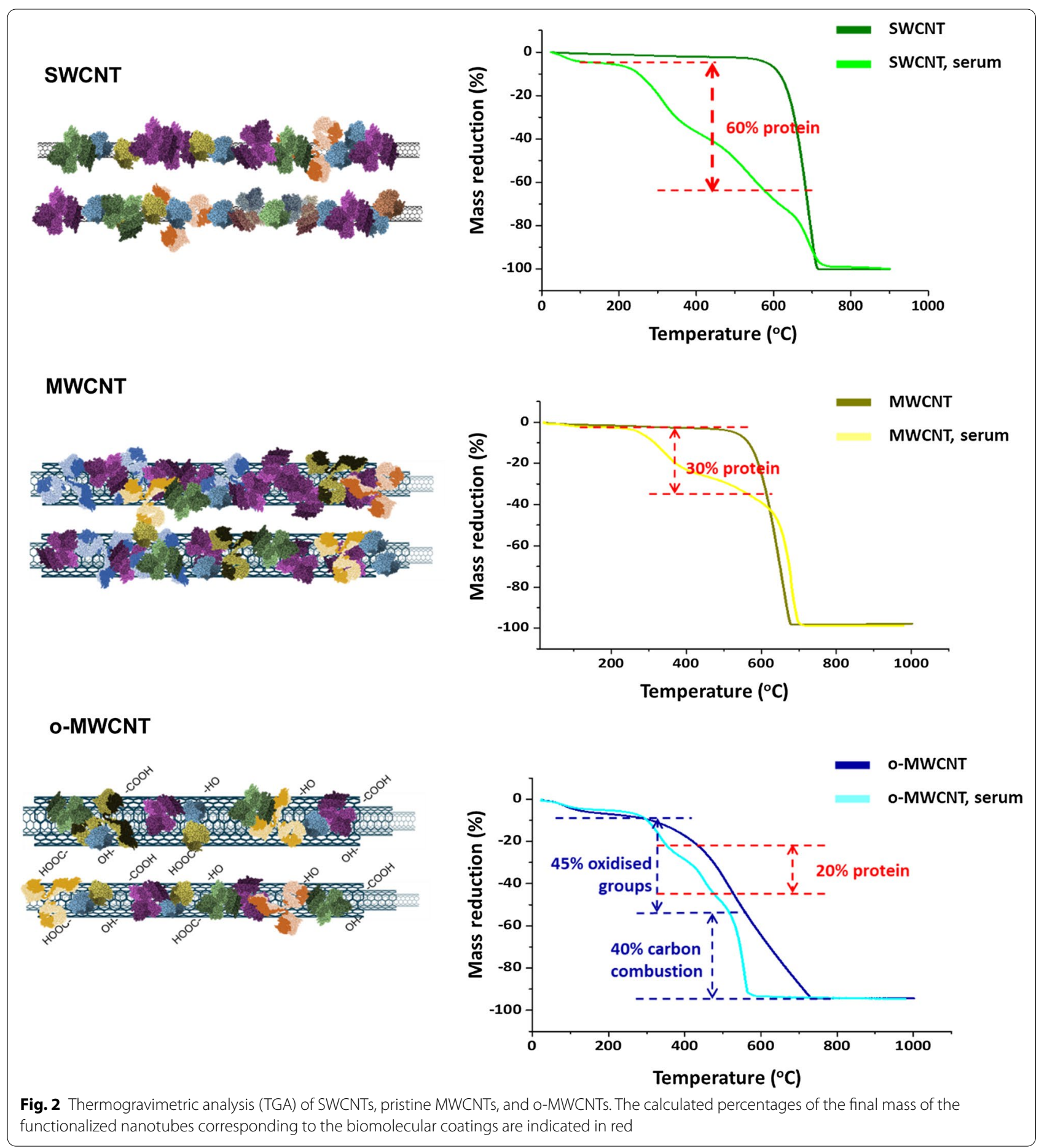

As a first approach, we compared pristine and oxidized MWCNTs (o-MWCNTs). These two types of nanotubes often fall into one category in nanobiotechnology/nanomedicine despite they are considered different from the physicochemical point of view. For the study, we used two varieties of nanotubes of each type -two types of o-MWCNTs, and two of pristine MWCNTs. The nanotubes were functionalized in the same bovine serum following identical protocols (Material and Methods). Interestingly, upon biochemical analysis, we found unique protein "landscapes" for each nanotube type. Figure 3 shows how proteins that are visible in one 
of the o-MWCNTs types are not detected in the other oxidized nanotube (red arrows). Similarly, the two types of MWCNTs used in the study produced very different protein peaks in the landscapes (red arrows) which suggests that small changes on the surface of the nanotube could be very critical in the interaction with environmental proteins.

Temperature is a key factor in protein folding and can significantly increase the flexibility and unfolding degree of polypeptides. Thus, the temperature at functionalization could also have important implications in nanomedicine since, depending on the preparation of the samples and their conservation, the in vivo behavior of CNTs could vary significantly [29]. Because of this, the next factor that we have analyzed was the influence of temperature on the interaction of proteins with CNTs as a function of time. To do this, we incubated a single representative type of (pristine) MWCNTs with a single type of serum at $37^{\circ} \mathrm{C}$ and $4{ }^{\circ} \mathrm{C}$ for different times. As in the previous section, we examined changes in the protein landscapes on the surfaces of the nanotubes using SDSPAGE analysis (Fig. 4, Additional file 1: Fig. S4). Figure 4 shows how nanotubes incubated at $37^{\circ} \mathrm{C}$ displayed fewer proteins in the range of $60-50 \mathrm{kDa}$ on their surfaces compared to the same nanotubes incubated with the same serum but at $4{ }^{\circ} \mathrm{C}$ during 24 and $48 \mathrm{~h}$ (red arrows). Again, these studies show how, for a single type of CNT, temperature and time conditions are critical factors in the final composition of the corona.

These findings suggest there could be small temperature-triggered conformational changes of the proteins that could cause changes in the composition of the corona, as observed in previous studies [19, 28]. From a biochemical point of view, physiological temperatures close to $37{ }^{\circ} \mathrm{C}$ allow proteins to be more dynamic and more flexible, and this could result in greater polypeptidic interaction with the surface of the nanotube. Most proteins, and serum albumin, in particular, exhibit great structural plasticity at physiological temperature and their polypeptides can spread over the surface of the CNTs, unfolding slightly, covering a larger surface of the nanotube, thus interfering with the binding of other proteins, more flexible or voluminous [29]. Interestingly, and as described for other types of nanomaterials [40], after $72 \mathrm{~h}$ of incubation, the originally adsorbed proteins were progressively replaced by others with different affinities for the nano-surface. However, these differences in the biocorona formed at 4 or $37^{\circ} \mathrm{C}$ did not result in clear differences in the percentage of protein captured in the total mass of the functionalized nanotubes (see TGA in Additional file 1: Fig. S5).

Preceding literature details with high precision the great variety of proteins that bind to CNTs when exposed to human serum, plasma, or other biologically relevant fluids $[17,39,41,42]$. Generally, studies agree that the most predominant proteins in these fluids, such as albumin, are present on the corona. However, each analysis lists a different list of proteins captured by the nanotubes. The different protein listings raise the question of what might happen if CNTs are exposed to sera from different human donors. Given our previous results, and to translate their significance in the context of nanomedicine, we now questioned if the same type of CNTs would interact with identical, or very similar, proteins upon exposure to different human sera. To investigate this issue, we exposed a single type of CNT to 4 different healthy human sera with known compositions (Additional file 1: Table S1). Interestingly, our results reveal that different sera interacted differently with the same type of CNTs. While some proteins do not appear on the surface of the nanotube and many changes their level of affinity (red/ blue arrows respectively, Fig. 5). This means that the same type of nanotube could behave completely differently in each patient depending on the peculiarities and properties of their serum. Thus, this finding has important biomedical implications, as it suggests that CNTs -as well as any other graphene-coated nanosystems [43-49], could have completely different effects in different patients.

Finally, to identify the protein landscape of the CNTs upon crossing the plasma membrane and binding intracellular proteins, we functionalized pristine MWCNTs and o-MWCNTs with a cell extract containing a mixture of intracellular proteins. To do this study, we chose human HeLa cells, a well-studied cervical carcinoma cell line in which CNTs have been shown to penetrate, triggering antiproliferative and pro-apoptotic effects [37]. On this occasion, the nanotubes were functionalized in a suspension of cytoplasmic intracellular proteins obtained from HeLa cell culture lysates. Figure 6 shows the distinctive protein profiles for the two types of nanotubes upon incubation with intracellular proteins. As expected, these protein patterns were also different from those observed when the nanotubes were functionalized with either bovine or human sera (Additional file 1: Fig. S7).

These results led us to design a predictable protein coating for nanotubes, to prevent non-specific interaction with the environmental proteins, a novel functionalization system that could also serve to improve CNTs targeting while preventing the activation of the immune responses and premature elimination of the nanotubes. For this purpose, we used genetic engineering to design a synthetic (recombinant) protein containing a peptide targeting the Human Epidermal Growth Factor Receptor 2 (HER2, also known as Neu or ErbB2). This receptor is overexpressed on the surface of multiple tumor cell types including breast [50,51], ovarian [52], lung 

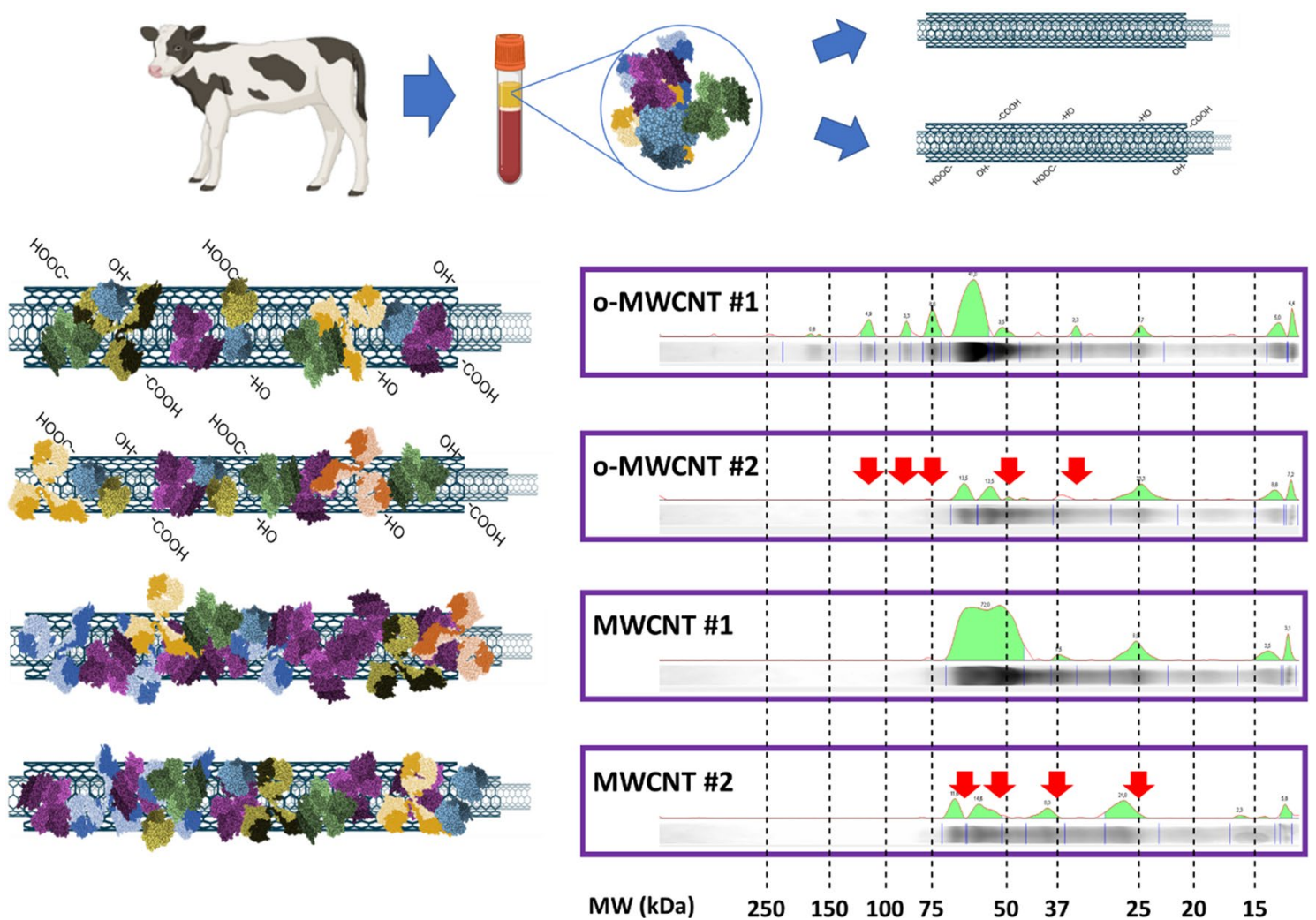

Fig. 3 Biochemical landscapes of o-MWCNTs and MWCNTs functionalized with the same bovine serum. The qualitative and semi-quantitative protein landscapes (green profiles) were calculated from the SDS-PAGE protein analysis (in horizontal). These profiles demonstrate how identical protein components interact very differently with each nanotube. Arrows indicate some of the most divergent protein peaks. Molecular weights (MW) of the proteins are indicated at the bottom of the figure. The full SDS-PAGE analysis is shown in Additional file 1: Figure S3
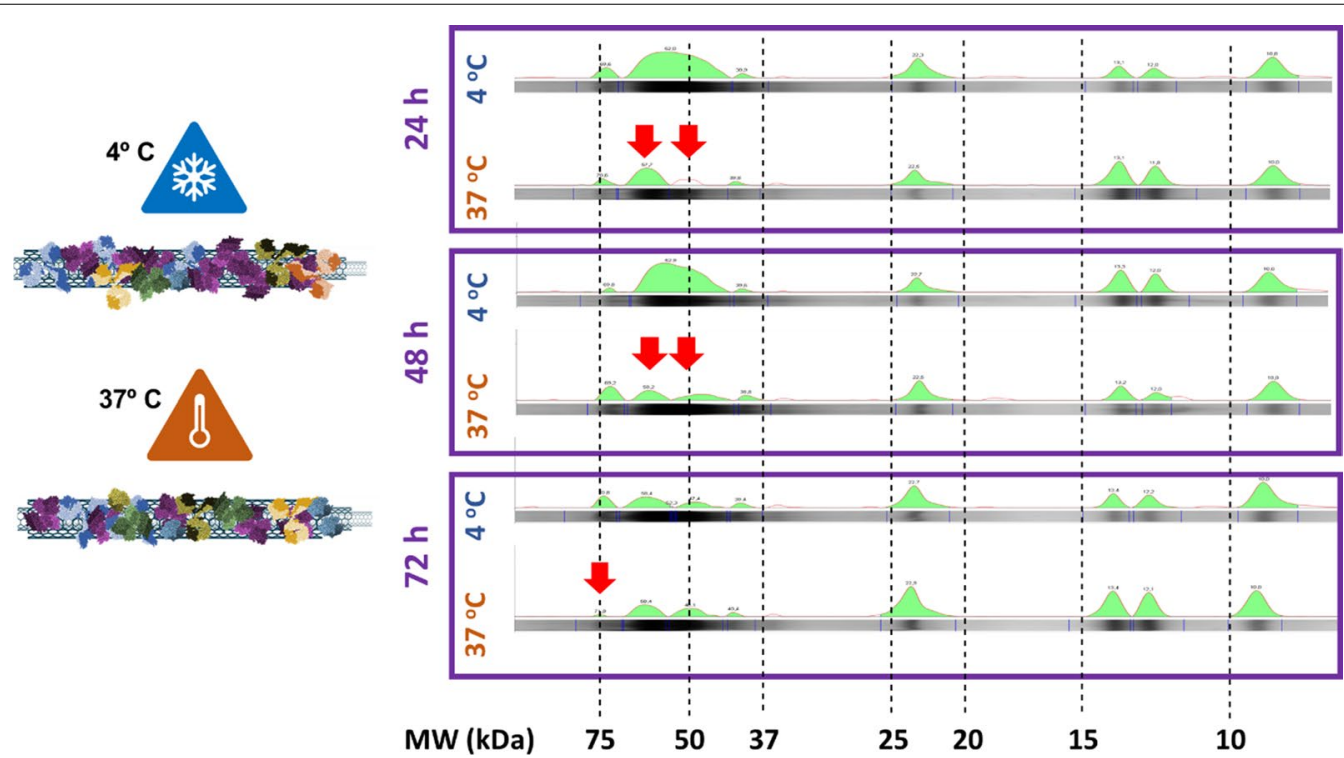

Fig. 4 Biochemical landscapes upon MWCNTs incubation with serum at $4^{\circ} \mathrm{C}$ or $37^{\circ} \mathrm{C}$. The protein landscapes obtained upon MWCNTs incubation with bovine serum at $4^{\circ} \mathrm{C}$ or $37^{\circ} \mathrm{C}$ during 24,48 , and $72 \mathrm{~h}$. SDS-PAGE analysis reveals how the same protein components interact very differently with the same nanotube as a function of temperature and time. Arrows indicate some of the most divergent protein peaks. Molecular weights (MW) of the proteins are indicated at the bottom of the figure. The full SDS-PAGE analysis is shown in Additional file 1: Figure S4 
[53], stomach, oral cancers [54] and, its relatively low expression on normal tissues makes it a clinically useful molecular target for directed therapies. The synthetic protein sequence designed contained: (i) a cationic CNT-binding peptide [55] in the N-terminus, (ii) a fluorescent reporting protein (GFP), and (iii) a the HER2-binding peptide [56] at the C-terminus (Fig. 7a). The CNT-binding domain consisted of a 10xHis cationic peptide that can be attached to most proteins. This peptide is useful in protein affinity purification and prevents recombinant protein direct interaction with the nanosurface of the CNTs, thus preventing ligand-protein denaturation. In this case, denaturation would be detected by protein fluorescence quenching. The synthetic HER2-binding protein (HER2bp) was produced in bacteria and was purified using affinity chromatography (Materials and Methods). Functionalization of the nanotubes was performed with saturating amounts of the HER2bp recombinant protein resuspended in PBS (Materials and Methods). Functionalized CNTs became fluorescent (Fig. 7b), thus indicating the recombinant GFP-fused protein was correctly folded (native) upon binding to the nanotube. This result is interesting in the context of preventing the activation of the immune system resulting from the denaturalization (unfolding) of the CNT-interacting proteins [29].

To investigate if functionalization with this synthetic protein served to control the unwanted interaction of the nanotube surface with nonspecific proteins of the environment, we incubated HER2bp-functionalized $\mathrm{CNTs}$ with bovine serum for $16 \mathrm{~h}$ at $30{ }^{\circ} \mathrm{C}$. Figure $7 \mathrm{c}$ shows the landscapes of (i) the purified HER2bp protein, (ii) the protein stripped of the as-prepared HER2bp-CNTs, and (iii) that of the same HER2bpCNTs after incubation with serum. The obtained biochemical landscapes demonstrate the efficiency of this functionalization method preventing protein denaturation and biofouling with unwanted environmental proteins (Additional file 1: Fig. S8). In summary, we demonstrate how the use of custom-made proteins, such as this HER2bp, can be a predictable way to functionalized CNTs for biomedical purposes.

\section{Discussion}

The unpredictability of the biocorona composition makes it impossible to predict the fate and effects of CNTs in the in vivo context. Here we show how the final protein assortment on the nanotubes depends on many factors, namely (i) the surrounding media, (ii) the temperature, (iii) the exposure time, (iv) the type of nanotube -concerning its size and reactivity-, and, more interestingly, the individuality of the human sera. Since all these factors are critical for in vivo applications, we have developed a way to predictably control the nanotube surface with synthetic proteins created and produced ad hoc. We have designed a cationic peptide to stably bind synthetic (recombinant) proteins to oxidized nanotubes, and demonstrate that this attachment protects the CNTs from unwanted interactions with the environmental proteins. Since these custommade CNT-binding proteins have a modular design, they can be designed ad-hoc according to the experimental needs simply by changing the targeting moieties, or fluorescent tags, to improve the predictability/ localization of CNTs in most biological environments. Besides, this design can also be used to functionalized two-dimensional graphene-based nanomaterials to create unique nanostructures for biomedical applications. These important changes in the biocorona are a notable issue to consider in the in vivo context as the affinities and surface charge of these nanomaterials change. These modifications are can cause a change in targeting and, consequently, in the toxicity and possible cumulative effect of these carbonous nanomaterials [47, 48].

\section{Conclusions}

Understanding and controlling the biomolecular coating on CNTs is the first step in nanobiotechnology and nanomedicine to be able to predict the biodistribution and effects of CNTs. This step is critical to producing reliable nanotherapies and nanovectors for in vivo applications. The protein corona endows CNTs with a biological identity that enables their intermingling with local components and participation in exquisite complementary molecular interactions [57]. These proteins determine the interaction of nanotubes with biological components, such as receptors, membranes, cytoskeletal filaments, etc., so understanding their variation and controlling their nature is essential in in vivo contexts. For this reason, we have developed a genetic engineering method to produce a stable custom-designed biocorona on nanotubes that allows predetermining the nature of the CNTs, and thus improve the biodistribution and effects of CNTs and CNT-based nanostructures.

\section{Materials and methods \\ CNTs}

Pristine MWCNTs $\left(\mathrm{NC} 3100^{\mathrm{TM}}\right)$ and oxidized MWCNTs (o-MWCNTs) $\left(\mathrm{NC}_{101}{ }^{\mathrm{TM}}\right.$ ) were purchased from Nanocyl. Pristine SWCNTs $(900,711)$ and MWCNTs $(698,849)$ (where indicated) from Sigma-Aldrich as powder. A characterization table is also provided (Additional file 1: Table S2). In-house o-MWCNTs were prepared as previously described $[58,59]$ using pristine MWCNTs $\left(\right.$ Nanocyl $\mathrm{NC} 100^{\mathrm{TM}}$ ) that were oxidized by sonication of 

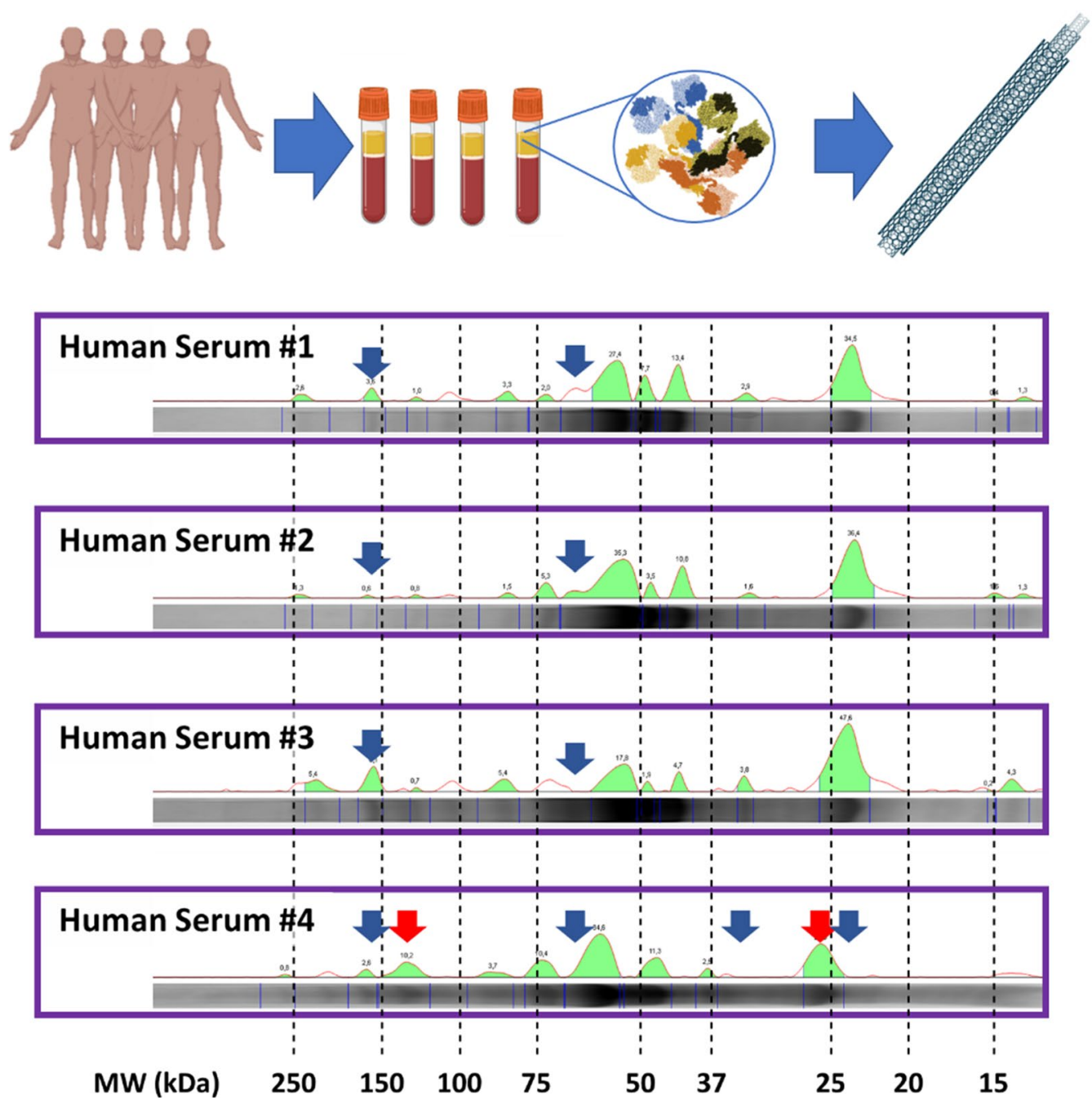

Fig. 5 Biochemical landscapes of MWCNTs functionalized with 4 different human sera. Biocorona protein profiles were obtained upon incubation of a single type of MWCNTs with 4 different healthy human sera during $24 \mathrm{~h}$. The biochemical landscapes reveal how the protein components of human sera interact differently with the same nanotube. Arrows indicate some of the most divergent protein peaks. Some proteins are completely absent in some of the samples (blue arrows) while others display significant changes in their affinity for the nanotube (red arrows). Molecular weights (MW) of the proteins are indicated at the bottom of the figure. The full SDS-PAGE analysis is shown in Additional file 1: Figure S6

a mixture of $\mathrm{H}_{2} \mathrm{SO}_{4} / \mathrm{HNO}_{3}(3: 1)$ at $37{ }^{\circ} \mathrm{C}$ for $9 \mathrm{~h}$ under continuous shaking. o-MWCNTs were washed with a $\mathrm{NaOH}$ aqueous solution by three centrifugation/redispersion cycles $(13,000 \mathrm{rpm})$. The acid solution was removed by filtration through a $0.45 \mu \mathrm{m}$ Teflon membrane and was washed in $\mathrm{H}_{2} \mathrm{O}$ until $\mathrm{pH} \sim 7$.

\section{CNTs characterization}

CNTs were characterized by thermogravimetric analysis, mass spectrometry, and FTIR in previous studies [60]. The unpolarized Raman spectra in Additional file 1: Fig. S1, S2 were taken with a Horiba T64000 triple spectrometer in the backscattering geometry, using the $514.5 \mathrm{~nm}$ line of a Coherent Innova Spectrum $70 \mathrm{C} \mathrm{Ar}+\mathrm{Kr}+$ laser and a nitrogen-cooled CCD (Jobin-Yvon Symphony) with a confocal microscope for detection. The laser beam was focused down to $1 \mu \mathrm{m}$ spot with a $100 \times$ objective and kept the power on the sample below $2 \mathrm{~mW}$ to avoid laser-heating effects on the probed material and the concomitant softening of the observed Raman peaks (Additional file 1: Fig. S1).

\section{Serum functionalization}

Functionalization of different CNTs was performed by nanomaterial dispersing in $30 \%$ serum protein solutions. CNTs were incubated at $37{ }^{\circ} \mathrm{C}$ for $24 \mathrm{~h}$ unless otherwise indicated in the text. CNTs dispersions were washed by 

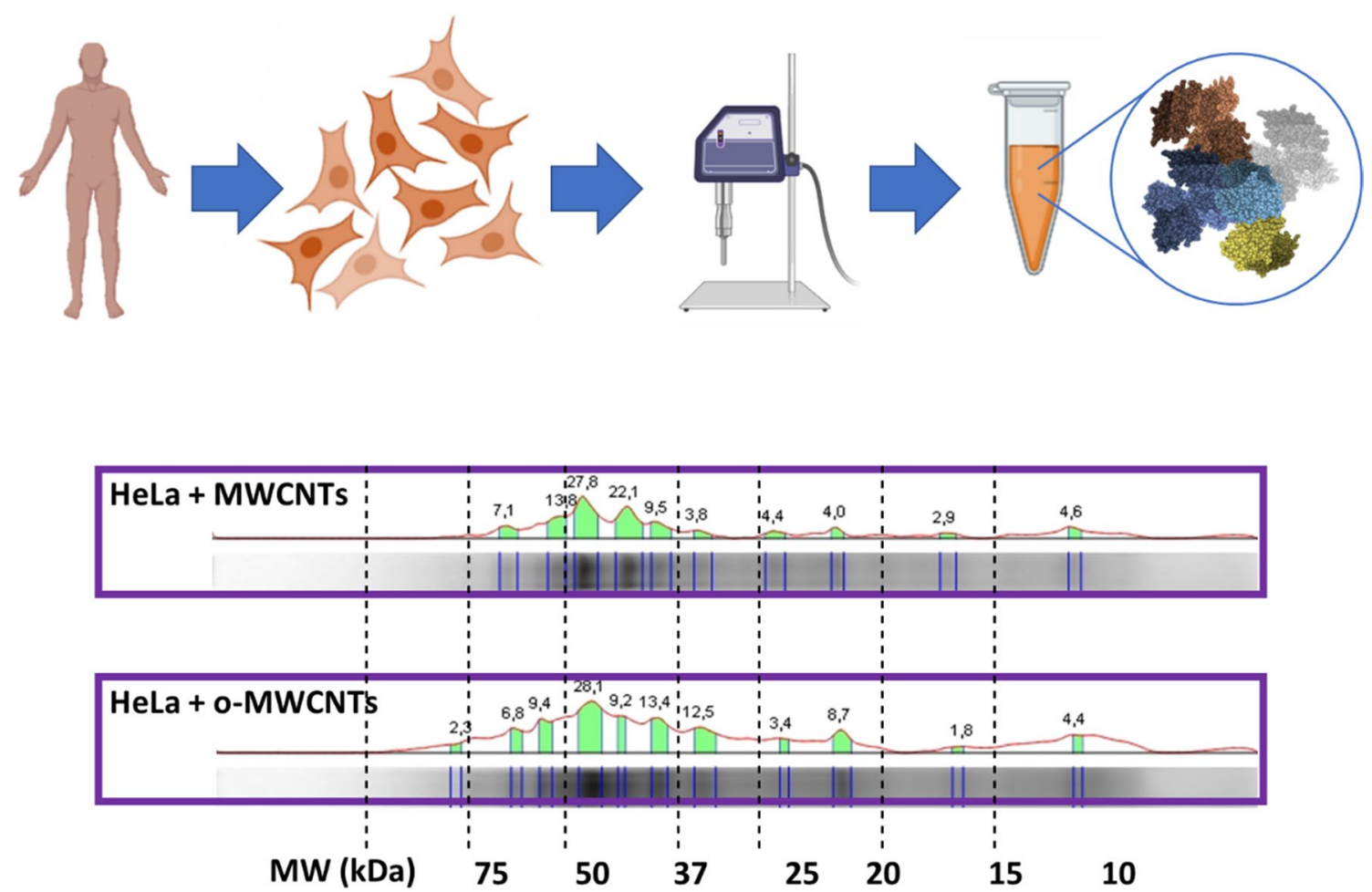

Fig. 6 Biochemical landscapes of MWCNTs and o-MWCNTs functionalized with human intracellular proteins. The two types of nanotubes interact differently with the intracellular proteins obtained from HeLa cells. The full SDS-PAGE analysis including comparison with bovine and human serum proteins is shown in Additional file 1: Figure S7

centrifugation for $2 \mathrm{~min}$ at 10,000 $g$. Their concentration was determined by optical absorption at $550 \mathrm{~nm}$ using a calibration curve as previously described $[61,62]$. Bovine serum (BS) was obtained from Gibco-Life Technologies (Cat No. 10108165). Human sera were collected from different donors at the Basque Center for Transfusion and Human Tissues (Additional file 1: Table S1). Sera were obtained by repeated cycles of vortex mixing followed by mild sonication (cycles of $5^{\prime \prime}$ on, $5^{\prime \prime}$ off, $10 \mathrm{~min}$, frequency of $38 \mathrm{kHz}$ ).

\section{HeLa protein lysate preparation and functionalization}

HeLa cells (ATCC ${ }^{\circledR}$ CCL-2) were cultured under standard conditions in Minimum Essential Medium containing 10\% serum, and ampicillin (1:1000). Approximately $10^{7}$ cells were harvested by trypsinization, washed with phosphate-buffered saline (PBS), and incubated in lysis buffer. The cells were broken by pipetting and the supernatant was separated by centrifugation $(13,000 \mathrm{rpm}$, $5 \mathrm{~min})$. HeLa cell-lysate supernatant proteins were mixed with $200 \mu \mathrm{g}$ o-MWCNTs were sonicated (5 min, $2 \mathrm{~s}$ pulses, $65 \%$ amplitude, $4{ }^{\circ} \mathrm{C}$ ), and were washed 3 times with PBS to remove the excess protein.

\section{TEM, AFM, TGA}

TEM images were obtained on JEOL JEM-2100 operating at $80 \mathrm{kV}$. Samples for TEM were prepared using ethanol as a dispersant and a drop of this suspension was adsorbed onto a lacey copper grid. Protein on CNTs was stained with lead citrate and uranyl acetate. AFM was performed using a WITec alpha-300 microscope on nanotube samples dried on a borosilicate glass coverslip. TGA was carried out using a Setaram Setsys Evolution 1700 apparatus, ranging from ca. 20-1000 ${ }^{\circ} \mathrm{C}$. Measurements were performed under an air atmosphere with a heating rate of $10{ }^{\circ} \mathrm{C} \mathrm{min}^{-1}$ at a total flow rate of $20 \mathrm{~mL} \mathrm{~min}^{-1}$.

\section{SDS-PAGE protein analysis}

SDS-PAGE was performed on CNTs incubated with the protein solutions after repeated washed by centrifugation. All samples analyzed contained $30 \mu \mathrm{gr}$ of functionalized CNTs. The nanotube concentration was determined by optical absorption as described previously [61]. Total protein on functionalized nanotubes was stripped with buffer Laemmli (0.125 M Tris- $\mathrm{HCl}$ pH 6.8, 20\% glycerol, $4 \%$ SDS, $2 \%$ mercaptoethanol, $0.02 \%$ bromophenol blue) 


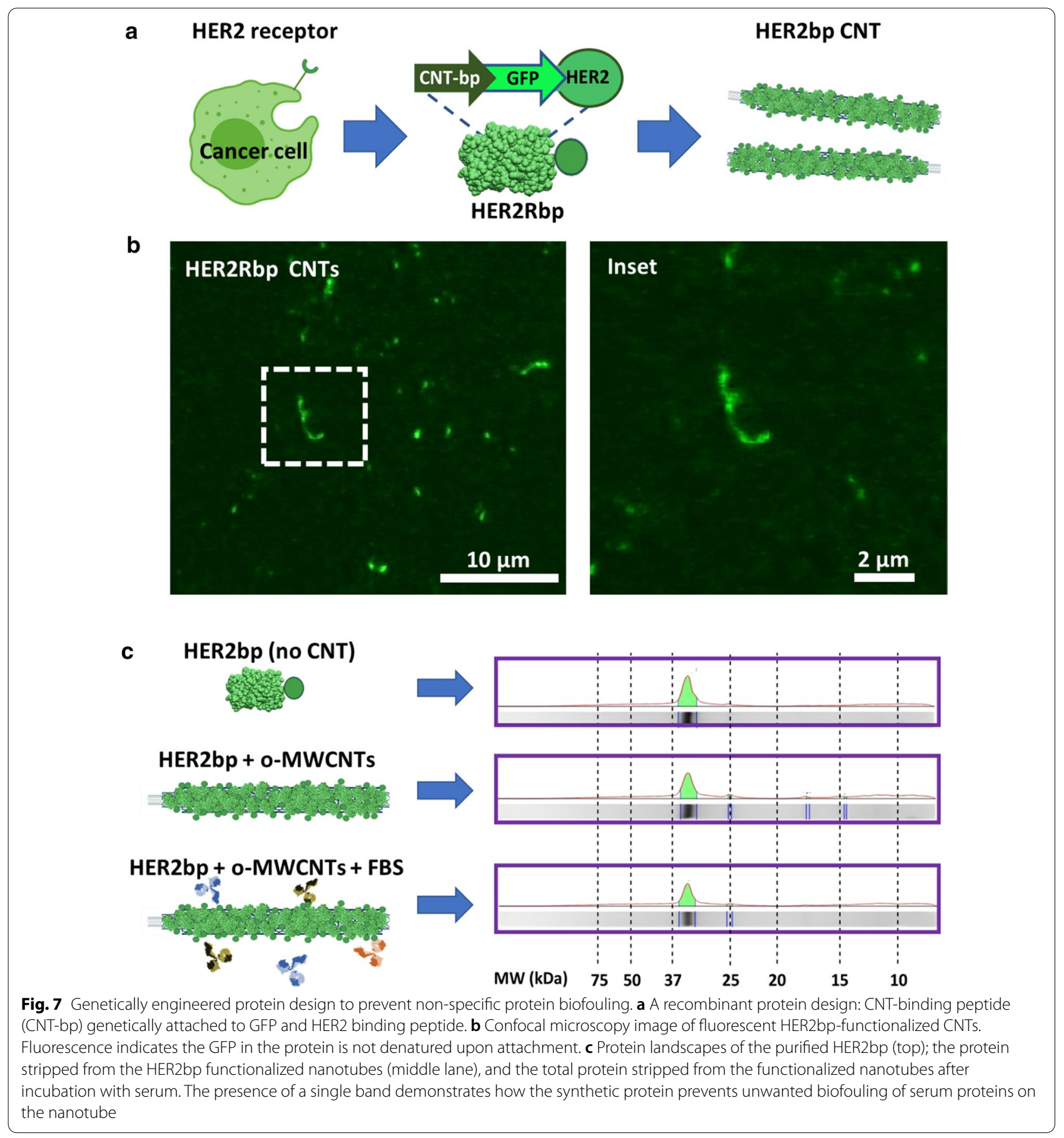

at $95{ }^{\circ} \mathrm{C}$ for $10 \mathrm{~min}$. The protein mixture was loaded on Mini-Protean ${ }^{\circledR}$ precast gels (BioRad) for SDS-PAGE analysis. The protein landscape analysis was obtained using Coomassie blue-stained gels that were scanned with a BioRad GelDoc EZ system. Protein patterning corresponds to Bio-Rad molecular weight standards.
Gene synthesis, protein expression, purification, and CNT functionalization

The recombinant gene was synthesized (General Biosystems) and was cloned in pET 15b plasmid systems (Novagen). One Shot ${ }^{\mathrm{TM}}$ BL21(DE3) E. coli (Thermo Fisher) cells were transformed with the expression vector. The clone 
was cultured in LB broth medium, and when the optical density was $0.5(590 \mathrm{~nm})$ then Isopropylb-D thiogalactopyranoside (1.0 mM IPTG, PanReac AppliChem) was added. After $6 \mathrm{~h}$ at room temperature incubation, cells were collected by centrifugation and were resuspended in LEW buffer $\left(50 \mathrm{mM} \mathrm{NaH} \mathrm{PO}_{4}\right.$ and $300 \mathrm{mM}$ $\mathrm{NaCl}$ in distilled water $\mathrm{pH}=8.0) .1 \mathrm{mg} / \mathrm{ml}$ lysozyme and protease inhibitor (Pierce, Thermo Fischer) were added to lyses bacterial cells. Bacterial cell lysates were obtained by probe sonication $(5 \times 15 \mathrm{~s}$ pulses at $130 \mathrm{~W}$, $65 \%$ amplitude, with $15 \mathrm{~s}$ intervals, $4{ }^{\circ} \mathrm{C}$ ) and insoluble material synthesized by centrifugation. Bacterial soluble protein lysate was loaded onto pre-equilibrated $\mathrm{Ni}$-TED columns (Protino ${ }^{\circledR} \mathrm{Ni}$-TED, Macherey-Nagel GmbH \& Co., Düren, Germany). Recombinant His-tagged protein was eluted in buffer supplemented with $250 \mathrm{mM}$ imidazole. PD-10 Desalting Columns (GE Healthcare, Chicago, USA) were used to remove the imidazole and exchange buffer to PBS. Finally, saturating amounts of the recombinant protein were mixed with $200 \mu \mathrm{g}$ o-MWCNTs, were sonicated ( $5 \mathrm{~min}, 2 \mathrm{~s}$ pulses, $65 \%$ amplitude, $4{ }^{\circ} \mathrm{C}$ ), and were washed 3 times with PBS to remove the excess protein.

\section{Confocal CNT imaging}

Functionalized CNTs were placed on a coverslip and imaged using a Nikon A1R confocal microscope $(100 \times 1.46$ n.a. lens $)$.

\section{Illustrations}

Illustrations have been created with the BioRender software available at BioRender.com.

\section{Supplementary Information}

The online version contains supplementary material available at https://doi. org/10.1186/s12951-021-00872-x.

Additional file 1. Additional figures and tables.

\section{Acknowledgements}

We are grateful to Ms. D. Muñoz, Drs R. Valiente, and E. González-Lavado, for their technical help and criticisms.

\section{Authors' contributions}

LGH, and MLF designed the study, performed experiments, and wrote the manuscript. JM provided the human sera samples. MS, NIR, EPG, FG, LGL, and $J \mathrm{G}$, contributed to the performance of experiments and experimental data analysis. All authors read and approved the final manuscript.

\section{Funding}

ISCIII Projects ref. PI19/00349, DTS19/00033, co-funded by ERDF/ESF, "Investing in your future"; and IDIVAL for the INNVAL 19/12, INNVAL 20/13 projects, and PREVAL18/02, PREVAL16/02, and PREVAL 16/03, and the technical support. LGL and LGH thank the ISCiii for the Sara Borrell Grants (ref. CD17/00105 and CD19/00035), and MS for the PFIS Grant (Ref. FI20/00023).
Availability of data and materials

All data and materials are included in this published article and its additional files.

\section{Declarations}

Consent for publication

All authors read and agreed to submit the manuscript.

\section{Competing interests}

All authors declare no competing interests.

\section{Author details}

${ }^{1}$ The Nanomedicine Group, University of Cantabria-IDIVAL, 39011 Santander, Spain. ${ }^{2}$ Osakidetza, Basque Center for Blood Transfusion and Human Tissues, Galdakao, Spain. Cell Therapy, Stem Cells and Tissues Group, Biocruces Bizkaia Health Research Institute, Barakaldo, Spain. ${ }^{3}$ Department of Chemistry and Process \& Resource Engineering, University of Cantabria, Barakaldo, Spain. ${ }^{4}$ Present Address: Istituto Italiano Di Tecnologia, Smart Bio-Interfaces, Viale Rinaldo Piaggio 34, 56025 Pontedera, Italy. ${ }^{5}$ Present Address: Department of Chemistry, Royal College of Surgeons in Ireland, Dublin D02 YN77, Ireland.

Received: 19 March 2021 Accepted: 24 April 2021

Published online: 05 May 2021

\section{References}

1. Salvati A, Pitek AS, Monopoli MP, Prapainop K, Bombelli FB, Hristov DR, et al. Transferrin-functionalized nanoparticles lose their targeting capabilities when a biomolecule corona adsorbs on the surface. Nat Nanotechnol. 2013;8:137-43.

2. Kostarelos K, Lacerda L, Pastorin G, Wu W, Wieckowski S, Luangsivilay J, et al. Cellular uptake of functionalized carbon nanotubes is independent of functional group and cell type. Nat Nanotechnol. 2007;2:108-13.

3. lijima S. Helical microtubules of graphitic carbon. Nature. 1991;354:56-8.

4. Peigney A, Laurent C, Flahaut E, Bacsa RR, Rousset A. Specific surface area of carbon nanotubes and bundles of carbon nanotubes. Carbon N Y. 2001;39:507-14.

5. Shen M, Xia X, Wang F, Zhang P, Zhao X. Influences of multiwalled carbon nanotubes and plant residue chars on bioaccumulation of polycyclic aromatic hydrocarbons by Chironomus plumosus larvae in sediment. Environ Toxicol Chem. 2012;31:202-9.

6. Shen X, Li S, Zhang H, Chen W, Yang Y, Li J, et al. Effect of multiwalled carbon nanotubes on uptake of pyrene by cucumber (Cucumis sativus L.): Mechanistic perspectives. Nanolmpact. 2018;10:168-76.

7. Jang MH, Hwang YS. Effects of functionalized multi-walled carbon nanotubes on toxicity and bioaccumulation of lead in Daphnia magna. PLoS ONE. 2018;13:1.

8. Panczyk T, Wolski P, Lajtar L. Coadsorption of Doxorubicin and Selected Dyes on Carbon Nanotubes. Theoretical Investigation of Potential Application as a pH-Controlled Drug Delivery System. Langmuir. 2016:32:4719-28.

9. Wang D, Hou C, Meng L, Long J, Jing J, Dang D, et al. Stepwise growth of gold coated cancer targeting carbon nanotubes for the precise delivery of doxorubicin combined with photothermal therapy. J Mater Chem B. 2017:5:1380-7.

10. Mehra NK, Palakurthi S. Interactions between carbon nanotubes and bioactives: a drug delivery perspective. Drug Discov Today. 2016;21:585-97.

11. Iqbal S, Rashid M, Arbab A, Khan M. Encapsulation of Anticancer Drugs (5-Fluorouracil and Paclitaxel) into Polycaprolactone (PCL) nanofibers and in vitro testing for sustained and targeted therapy. J Biomed Nanotechnol. 2017;13:355-66.

12. Nivethaa EAK, Dhanavel S, Rebekah A, Narayanan V, Stephen A. A comparative study of 5-Fluorouracil release from chitosan/silver and chitosan/ silver/MWCNT nanocomposites and their cytotoxicity towards MCF-7. Mater Sci Eng C. 2016;66:244-50.

13. Salehi $R$, Rasoolzadeh R. Investigation of Capecitabine and 5-fluorouracil anticancer drugs structural properties and their interactions with 
single-walled carbon nanotube: insights from computational methods. Biointerface Res Appl Chem. 2018;8:3075-83.

14. Kam NWS, Liu Z, Dai H. Carbon nanotubes as intracellular transporters for proteins and DNA: an investigation of the uptake mechanism and pathway. Angew Chemie. 2006:45:577-81.

15. Varkouhi AK, Foillard S, Lammers T, Schiffelers RM, Doris E, Hennink WE, et al. SiRNA delivery with functionalized carbon nanotubes. Int J Pharm. 2011;416:419-25.

16. Neves V, Heister E, Costa S, Tîlmaciu C, Flahaut E, Soula B, et al. Design of double-walled carbon nanotubes for biomedical applications. Nanotechnology. 2012;23:365102.

17. Cai $X$, Ramalingam R, Wong HS, Cheng J, Ajuh P, Cheng SH, et al. Characterization of carbon nanotube protein corona by using quantitative proteomics. Nanomed Nanotechnol Biol Med. 2013;9:583-93.

18. Sacchetti C, Motamedchaboki K, Magrini A, Palmieri G, Mattei M, Bernardini S, et al. Surface polyethylene glycol conformation influences the protein corona of polyethylene glycol-modified single-walled carbon nanotubes: potential implications on biological performance. ACS Nano. 2013;7:1974-89.

19. Zhao X, Lu D, Hao F, Liu R. Exploring the diameter and surface dependent conformational changes in carbon nanotube-protein corona and the related cytotoxicity. J Hazard Mater. 2015;292:98-107.

20. De Paoli SH, Diduch LL, Tegegn TZ, Orecna M, Strader MB, Karnaukhova $E$, et al. The effect of protein corona composition on the interaction of carbon nanotubes with human blood platelets. Biomaterials. 2014;35:6182-94.

21. Nicoletti M, Capodanno C, Gambarotti C, Fasoli E. Proteomic investigation on bio-corona of functionalized multiwalled carbon nanotubes. Biochim Biophys Acta - Gen Subj. 2018;1862:2293-303.

22. Yaron PN, Holt BD, Short PA, Lösche M, Islam MF, Dahl KN. Single wall carbon nanotubes enter cells by endocytosis and not membrane penetration. J Nanobiotechnol. 2011;9:45.

23. Haniu H, Saito N, Matsuda Y, Tsukahara T, Maruyama K, Usui Y, et al. Culture medium type affects endocytosis of multi-walled carbon nanotubes in BEAS-2B cells and subsequent biological response. Toxicol Vitr. 2013;27:1679-85.

24. Ju L, Zhang G, Zhang X, Jia Z, Gao X, Jiang Y, et al. Proteomic analysis of cellular response induced by multi-walled carbon nanotubes exposure in A549 cells. PLoS ONE. 2014;9:1

25. Maruyama K, Haniu H, Saito N, Matsuda Y, Tsukahara T, Kobayashi S, et al. Endocytosis of multiwalled carbon nanotubes in bronchial epithelial and mesothelial cells. Biomed Res Int 2015:2015:793186.

26. Salvador-Morales C, Flahaut E, Sim E, Sloan J, Green MLH, Sim RB. Complement activation and protein adsorption by carbon nanotubes. Mol Immunol. 2006:43:193-201.

27. Roztoczyńska A, Kozłowska J, Lipkowski P, Bartkowiak W. Hydrogen bonding inside and outside carbon nanotubes: HF dimer as a case study. Phys Chem Chem Phys. 2016;18:2417-27.

28. Vaitheeswaran S, Garcia AE. Protein stability at a carbon nanotube interface. J Chem Phys. 2011;134:125101.

29. Park JY, Park SJ, Park JY, Kim SH, Kwon S, Jung YJ, et al. Unfolded protein corona surrounding nanotubes influence the innate and adaptive immune system. Adv Sci. 2021;2004979:1-14.

30. Hirsch A, Backes C. Carbon nanotube science. Synthesis, properties and applications. Angew Chemie Int Ed. 2010:49:1722-3.

31. Rodríguez-Fernández L, Valiente R, González J, Villegas JC, Fanarraga ML. Multiwalled carbon nanotubes display microtubule biomimetic properties in vivo, enhancing microtubule assembly and stabilization. ACS Nano. 2012;6:6614-25.

32. Lanone S, Andujar P, Kermanizadeh A, Boczkowski J. Determinants of carbon nanotube toxicity. Adv Drug Deliv Rev. 2013;65:2063-9.

33. Wang JTW, Fabbro C, Venturelli E, Menard-Moyon C, Chaloin O, Da Ros T, et al. The relationship between the diameter of chemically-functionalized multi-walled carbon nanotubes and their organ biodistribution profiles in vivo. Biomaterials. 2014;35:9517-28.

34. Nagai H, Okazaki Y, Chew SH, Misawa N, Yamashita Y, Akatsuka S, et al. Diameter and rigidity of multiwalled carbon nanotubes are critical factors in mesothelial injury and carcinogenesis. Proc Natl Acad Sci USA. 2011;108:1330-E1338
35. Siegrist KJ, Reynolds SH, Kashon ML, Lowry DT, Dong C, Hubbs AF, et al. Genotoxicity of multi-walled carbon nanotubes at occupationally relevant doses. Part Fibre Toxicol. 2014:11:6.

36. Kisin ER, Murray AR, Keane MJ, Shi XC, Schwegler-Berry D, Gorelik O, et al. Single-walled carbon nanotubes: Geno- and cytotoxic effects in lung fibroblast V79 cells. J Toxicol Environ Heal - Part A Curr Issues. 2007;70:2071-9.

37. Garcia-Hevia L, Valiente R, Fernandez-Luna JL, Flahaut E, RodriguezFernandez L, Villegas JC, et al. Inhibition of cancer cell migration by multiwalled carbon nanotubes. Adv Healthc Mater. 2015;4:1640-4.

38. Dong C, Eldawud R, Sargent LM, Kashon ML, Lowry D, Rojanasakul Y, et al. Carbon nanotube uptake changes the biomechanical properties of human lung epithelial cells in a time-dependent manner. J Mater Chem B. 2015;3:3983-92.

39. Shannahan JH, Brown JM, Chen R, Ke PC, Lai X, Mitra S, et al. Comparison of nanotube-protein corona composition in cell culture media. Small. 2013;9:2171-81.

40. Monopoli MP, Åberg C, Salvati A, Dawson KA. Biomolecular coronas provide the biological identity of nanosized materials. Nat Nanotechnol. 2012;7:779-86.

41. Sopotnik M, Leonardi A, Križaj I, Dušak P, Makovec D, Mesarič T, et al. Comparative study of serum protein binding to three different carbon-based nanomaterials. Carbon NY. 2015;95:560-72.

42. Madani SY, Tan A, Dwek M, Seifalian AM. Functionalization of singlewalled carbon nanotubes and their binding to cancer cells. Int J Nanomed. 2012;7:905-14.

43. Wei G, Su Z. Motif-tailoring enriches the biofunctions of self-assembled peptide superstructures. Curr Org Chem. 2018;22:1947-8.

44. Zhang X, Gong C, Akakuru OU, Su Z, Wu A, Wei G. The design and biomedical applications of self-assembled two-dimensional organic biomaterials. Chem Soc Rev. 2019:1:5564-95.

45. Hajipour MJ, Raheb J, Akhavan O, Arjmand S, Mashinchian O, Rahman M, et al. Personalized disease-specific protein corona influences the therapeutic impact of graphene oxide. Nanoscale. 2015;7:8978-94.

46. Di Santo R, Digiacomo L, Quagliarini E, Capriotti AL, Laganà A, Zenezini Chiozzi R, Caputo D, Cascone C, Coppola R, Pozzi D, Caracciolo G. Personalized graphene oxide-protein corona in the human plasma of pancreatic cancer patients. Front Bioeng Biotechnol. 2020;8:491.

47. Mbeh DA, Akhavan O, Javanbakht T, Mahmoudi M, Yahia L. Cytotoxicity of protein corona-graphene oxide nanoribbons on human epithelial cells. Appl Surf Sci. 2014;320:596-601.

48. Assali A, Razzazan S, Akhavan O, Mottaghitalab F, Adeli M, Atyabi F. The bio-interface between functionalized Au NR@GO nanoplatforms with protein corona and their impact on delivery and release system. Colloids Surf B Biointerfaces. 2019;173:891-8.

49. Zhang W, Yu X, Li Y, Su Z, Jandt KD, Wei G. Protein-mimetic peptide nanofibers: Motif design, self-assembly synthesis, and sequence-specific biomedical applications. Prog Polym Sci. 2018;1:94-124.

50. Oh DY, Bang YJ. HER2-targeted therapies - a role beyond breast cancer. Nat Rev Clin Oncol. 2020;1:33-48.

51. Bartlett JMS, Going JJ, Mallon EA, Watters AD, Reeves JR, Stanton P, et al Evaluating HER2 amplification and overexpression in breast cancer. J Pathol. 2001:195:422-8.

52. Berchuck A, Kamel A, Whitaker R, Kerns B, Olt G, Kinney R, et al. Overexpression of HER-2/neu is associated with poor survival in advanced epithelial ovarian cancer. Cancer Res. 1990;50:1.

53. Liu L, Shao X, Gao W, Bai J, Wang R, Huang P, et al. The role of human epidermal growth factor receptor 2 as a prognostic factor in lung cancer: a meta-analysis of published data. J Thorac Oncol. 2010;5:1922-32.

54. Albarello L, Pecciarini L, Doglioni C. HER2 testing in gastric cancer. Adv Anat Pathol. 2011;18:53-9.

55. Padín-González E, Navarro-Palomares E, Valdivia L, Iturrioz-Rodríguez N, Correa MA, Valiente R, et al. A custom-made functionalization method to control the biological identity of nanomaterials. Nanomed Nanotechnol Biol Med. 2020;29:102268.

56. Geng L, Wang Z, Yang X, Li D, Lian W, Xiang Z, et al. Structure-based design of peptides with high affinity and specificity to HER2 positive tumors. Theranostics. 2015;5:1154-65.

57. Walczyk D, Bombelli FB, Monopoli MP, Lynch I, Dawson KA. What the cell "sees": in bionanoscience. J Am Chem Soc. 2010;132:5761-8. 
58. Gonzalez-Lavado E, Iturrioz-Rodriguez N, Padin-González E, Gonzalez JA, Garcia-Hervia L, Heuts J, et al. Biodegradable multi-walled carbon nanotubes trigger anti-tumoral effects. Nanoscale. 2018;10:11013-20.

59. Iturrioz-Rodríguez N, González-Domínguez E, González-Lavado E, MarínCaba L, Vaz B, Pérez-Lorenzo MM, et al. A biomimetic escape strategy for cytoplasm invasion by synthetic particles. Angew Chemie Int Ed. 2017:56:13736-40.

60. González-Lavado E, Iturrioz-Rodríguez N, Padín-González E, González J, García-Hevia L, Heuts J, et al. Biodegradable multi-walled carbon nanotubes trigger anti-tumoral effects. Nanoscale. 2018;10:11013-20.

61. González-Legarreta L, Renero-Lecuna C, Valiente R, Fanarraga ML. Development of an accurate method for dispersion and quantification of carbon nanotubes in biological media. Anal Methods. 2020;12:5642-7.
62. García-Hevia L, Valiente R, Fernández-Luna JL, Flahaut E, RodríguezFernández L, Villegas JC, et al. Inhibition of cancer cell migration by multiwalled carbon nanotubes. Adv Healthc Mater. 2015:4:1640-4.

\section{Publisher's Note}

Springer Nature remains neutral with regard to jurisdictional claims in published maps and institutional affiliations.
Ready to submit your research? Choose BMC and benefit from:

- fast, convenient online submission

- thorough peer review by experienced researchers in your field

- rapid publication on acceptance

- support for research data, including large and complex data types

- gold Open Access which fosters wider collaboration and increased citations

- maximum visibility for your research: over 100M website views per year

At BMC, research is always in progress.

Learn more biomedcentral.com/submissions 